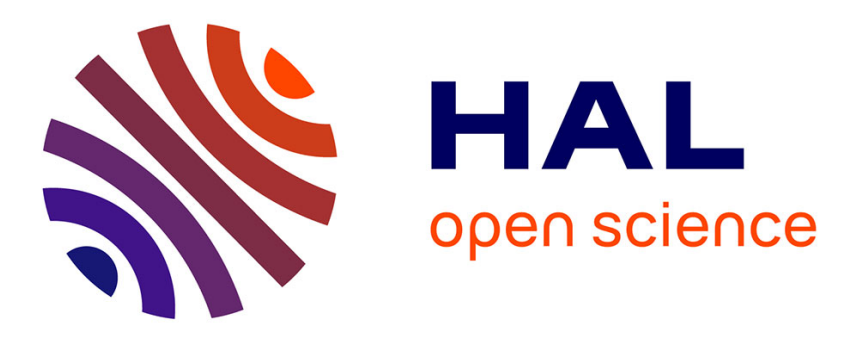

\title{
Susceptibility variation to the main pathogens of Crassostrea gigas at the larval, spat and juvenile stages using unselected and selected oysters to OsHV-1 and/or V. aestuarianus
}

Lionel Dégremont, Benjamin Morga, Elise Maurouard, Marie-Agnes Travers

\section{To cite this version:}

Lionel Dégremont, Benjamin Morga, Elise Maurouard, Marie-Agnes Travers. Susceptibility variation to the main pathogens of Crassostrea gigas at the larval, spat and juvenile stages using unselected and selected oysters to OsHV-1 and/or V. aestuarianus. Journal of Invertebrate Pathology, 2021, 183, pp.107601. 10.1016/j.jip.2021.107601 . hal-03228425

\section{HAL Id: hal-03228425 \\ https://hal.science/hal-03228425}

Submitted on 18 May 2021

HAL is a multi-disciplinary open access archive for the deposit and dissemination of scientific research documents, whether they are published or not. The documents may come from teaching and research institutions in France or abroad, or from public or private research centers.
L'archive ouverte pluridisciplinaire $\mathbf{H A L}$, est destinée au dépôt et à la diffusion de documents scientifiques de niveau recherche, publiés ou non, émanant des établissements d'enseignement et de recherche français ou étrangers, des laboratoires publics ou privés. 
Susceptibility variation to the main pathogens of Crassostrea gigas at the larval, spat and juvenile stages using unselected and selected oysters to OsHV-1 and/or V. aestuarianus

Lionel Dégremont $^{1}$, Benjamin Morga ${ }^{1}$, Elise Maurouard ${ }^{1}$, Marie-Agnès Travers ${ }^{2}$

${ }^{1}$ SG2M, LGP2M, Ifremer, La Tremblade, France

${ }^{2}$ IHPE, Université de Montpellier, CNRS, Ifremer, Université de Perpignan Via Domitia. F34090 Montpellier, France

*Corresponding author. Tel.: +33 5467626 30; fax: +33 546762611 .

E-mail address: lionel.degremont@ifremer.fr (L. Dégremont).

Running title: Experimental infection by several pathogens in C. gigas at different life stages 


\section{ABSTRACT}

French commercial hatcheries are massively producing Crassostrea gigas selected for their higher resistance to OsHV-1, and soon should also implement selection for increasing resistance to Vibrio aestuarianus. The first objective of this study was to optimize the breeding programs for dual resistance to OsHV-1 and V. aestuarianus to determine the earliest life stage for which oysters are able to develop disease resistance. Wild stocks and selected families were tested using experimental infections by both pathogens at the larval, spat and juvenile stages. Oyster families could be evaluated for OsHV-1 as soon as the larval stage by a bath method, but this only highlighted the most resistant families; those that showed the highest resistance to V. aestuarianus could be determined using the cohabitation method at the juvenile stage.

The second objective of this study was to determine if selection to increase/decrease the resistance to OsHV-1 and $V$. aestuarianus could have an impact on other major pathogens currently detected in hatchery at the larval stage, and in nursery and field at the spat/juveniles stages (V. coralliilyticus, V. crassostreae, V. tasmaniensis, V.neptunius, V. europaeus, V. harveyi, $V$. chagasi). No relationship was found between mortality caused by $V$. aestuarianus/OsHV-1 and the mortality caused by the other virulent bacterial strains tested regardless the stages, except between OsHV-1 and V. tasmaniensis at the juvenile stage.

Finally, miscellaneous findings were evidenced such as (1) bath for bacterial challenges was not adapted for spat, (2) the main pathogens at the larval stage were OsHV-1 and $V$. coralliilyticus using bath, while it was V. coralliilyticus, V. europaeus, and V. neptunius at the juvenile stage by injection, and (4) variation in mortality was observed among families/wild controls for all pathogens at larval and juvenile stages, except for $V$. harveyi for larvae.

Keywords: Crassostrea gigas; OsHV-1; V. aestuarianus; Vibrio spp; selection 


\section{Introduction}

Selective breeding to enhance disease resistance has been successful in many oyster species (Dégremont et al., 2015a). Usually most of the studies investigate one pathogen, such as Roseovarius crassostrea in Crassostrea virginica (Barber et al., 1998) or Bonamia ostreae in Ostrea edulis (Culloty et al., 2001; Naciri-Graven et al., 1998); or two pathogens, as described for Perkinsus marinus and Haplosporidium nelsoni in C. virginica (Frank-Lawale et al., 2014; Ragone Calvo et al., 2003), Bonamia roughleyi and Marteilia sydneyi in Saccostrea glomerata (Dove et al., 2013), and the ostreid herpesvirus type 1 (OsHV-1) and Vibrio aestuarianus in Crassostrea gigas (Azéma et al., 2015).

Since 2008, French oyster production, mostly based on C. gigas, has been threatened by the Ostreid herpesvirus $1(\mathrm{OsHV}-1)$ with high mortality rates of over $70 \%$ for spat and juveniles. In addition, market-size adults have displayed mortality due to the bacterium Vibrio aestuarianus since 2012 (Azéma et al., 2015). As a response, selective breeding programs have been developed to enhance as well as to decrease OsHV-1 resistance at the spat stage in $C$. gigas (Dégremont, 2011; Dégremont et al., 2015b), and such a strategy is currently under investigation for $V$. aestuarianus, based on the results obtained by Azéma et al. (2017b) who showed a low to moderate genetic basis for resistance to this pathogen at juvenile and adult stages. More importantly, they found the absence of genetic correlation between the resistance to OsHV-1 infection and the resistance to V. aestuarianus infection, suggesting that it could be possible to develop oyster lines in C. gigas with either resistance to one of the two diseases, dual susceptibility, or dual resistance to OsHV-1 and V. aestuarianus. Nevertheless, such selection could alter the susceptibility of C. gigas to other pathogens, such as those frequently detected during mortality outbreaks in hatcheries and nurseries, if a negative or positive genetic correlation exists, as observed in rainbow trout between Piscirickettsia. salmonis resistance and 
Caligus rogercresseyi susceptibility (Bassini et al., 2019), and between resistance to Flavobacterium psychrophilum and resistance to Flavobacterium columnare (Silva et al., 2019), respectively.

Beside OsHV-1 and V. aestuarianus, other pathogens can induce high mortality in C. gigas. For instance, Vibrio coralliilyticus and Vibrio neptunius causes high larval mortality (Prado et al., 2005; Richards et al., 2015). Similarly, larvae, juvenile and adults showed high mortality due to Vibrio tubiashii and the close relative Vibrio europaeus (Dubert et al., 2016; Elston et al., 2008; Mersni-Achour et al., 2015; Travers et al., 2014). Spat and juveniles are also susceptible to Vibrio harveyi (Saulnier et al., 2010), Vibrio crassostreae (Bruto et al., 2017), and Vibrio splendidus-related LGP32 (Gay et al., 2004), the latter being assigned to V. tasmaniensis (Sawabe et al., 2013).

Our study investigates the susceptibility of nine families selected to decrease or increase their resistance to OsHV-1 and/or V. aestuarianus and three wild stocks at the larval, spat and juvenile stages. The 12 groups of oysters were challenged with OsHV-1 and V.aestuarianus, as well as V. coralliilyticus, V. crassostreae, V. tasmaniensis, V. harveyi, V.neptunius, and V. europaeus. In addition, juvenile oysters were also tested against $V$. chagasii. The two main objectives were (1) to determine which stage was the best to identify to the susceptibility or the resistance for OsHV-1 and V. aestuarianus, and (2) to evaluate if any relationship exists in performance under challenge with one of these two pathogens and with other pathogenic strains of Vibrio.

\section{Materials and methods}

\subsection{Oyster broodstocks}


Three wild stocks collected from the Marennes-Oléron Bay in January 2016 and nine families with various levels of susceptibility to OsHV-1 and V. aestuarianus, the latter named from F1 to F9, were used (Table 1). The level of susceptibility of the families was defined at the juvenile stage for oysters weighing around $10-15 \mathrm{~g}$, and using a cohabitation method with donors injected with one of the two pathogens. Eight (F1 to F8) of them were produced from wild oysters in March 2013 and their disease susceptibility was evaluated as described in Azéma et al. (2017b). The last family (F9), produced in February 2014, used a female of the family F8 crossed with a male from the third generation of a mass selection scheme to increase OsHV-1 resistance as described in Dégremont et al. (2015b). No family had a common ancestor, meaning that the inbreeding rate $(F)$ is assumed to be null, as it was for the three stocks of wild oysters sampled in the Marennes-Oléron Bay (Table 1).

\subsection{Oyster production}

In January 2016, the nine families and the three wild stocks were placed in separate tanks in the conditioning room at the Ifremer hatchery in La Tremblade until the spawn. Indeed, wild stocks may have contained asymptomatic adults infected with OsHV-1, V. aestuarianus or other pathogens. Thus, separate holding avoided potential horizontal transmission of pathogens from the wild stocks to the families, in particular the susceptible ones, as they were always protected in our facilities using UV-treated seawater $(40 \mathrm{mj} / \mathrm{cm} 2)$, and so they never experienced mortality outbreaks. The seawater temperature was increased and maintained to $20^{\circ} \mathrm{C}$, and a cultured phytoplankton diet (Isochrysis galbana, Tetraselmis suecica and Skeletonema costatum) was provided to favor gametogenesis.

The spawn occurred in March 2016. For each of the families and wild stocks, oysters were placed into a 5-L glass beaker filled alternatively with unheated or heated seawater to $28^{\circ} \mathrm{C}$ to 
induce the spawn. The number of oysters used per stock is reported in Table 1. As soon as the first gametes were released, seawater was maintained at $25^{\circ} \mathrm{C}$. Every 15 minutes, the water was sieved and fertilized eggs were collected on a $20-\mu \mathrm{m}$ screen and transferred to a $30-\mathrm{L}$ tank. The empty beaker containing the parents was refilled in order for them to continue to spawn. This occurred until the end of the spawning event to maximize the effective population size for each stock.

The methodology used for the larval and spat cultures is described in Dégremont et al. (2005) and Dégremont et al. (2007). All oyster groups were kept in our controlled facilities using UVtreated seawater until their evaluations either under experimental infections by $V$. aestuarianus or OsHV-1 or under field conditions where both pathogens have been regularly detected in moribund oysters (Azéma et al., 2017a).

2.3. Preparation of viral suspension and contaminated seawater

Viral suspensions were prepared according to Schikorski et al. (2011). In brief, gills and mantles from OsHV-1 $\mu$ Var-infected oyster spat were dissected and pooled together in a 50-mL sterile tube. All subsequent dilutions were made with $0.22-\mu \mathrm{m}$-filtered artificial seawater (ASW). The total mass of the tissues was weighed, and 10 volumes of $0.22-\mu \mathrm{m}$ ASW were added to the tube ( $9 \mathrm{~mL}$ of seawater per $\mathrm{g}$ of tissue). The tissues were then crushed on ice with an Ultra-Turrax ${ }^{\circledR}$ mixer $(3 \times 5 \mathrm{~s})$. Following centrifugation $\left(1000 \mathrm{~g}, 5 \mathrm{~min}, 4^{\circ} \mathrm{C}\right)$, the supernatant was placed in a new tube and diluted by adding four volumes of ASW. Finally, the clarified tissue homogenate was filtered consecutively through syringe filters at $5,2,0.45$, and $0.22-\mu \mathrm{m}$ pore sizes under sterile conditions. Filtered tissue homogenates were stored at $4^{\circ} \mathrm{C}$ until use and the concentration of the viral suspension obtained was $3.3 \times 10^{5} \mu 1^{-1}$ copies of viral DNA. 
For the experimental infections at the larval stage, $100 \mu l$ of viral suspension was added to each well corresponding to a final concentration of $10^{4}$ OsHV-1 DNA copies $\mu 1^{-1}$. For the experimental infections at the spat and juvenile stages, contaminated seawater was prepared through injection of 12 oysters with $100 \mu l$ of the viral suspension. The injected oysters were maintained in a 3-L tank filled with UV-treated, filtered and aerated seawater for $24 \mathrm{~h}$. Contaminated seawater surrounding oysters was added to each well for spat $\left(4.7 \mathrm{x} 10^{3}\right.$ DNA copies $\left.\mu 1^{-1}\right)$ or in tanks for juveniles $\left(5.3 \times 10^{3}\right.$ DNA copies $\left.\mu 1^{-1}\right)$.

\subsection{Preparation of contaminated seawater for several pathogenic strains of Vibrio}

Bacteria were initially grown on Zobell agar (peptone $4 \mathrm{~g} / \mathrm{L}$, yeast extract $1 \mathrm{~g} / \mathrm{L}$, Tris buffer 0.5 $\mathrm{g} / \mathrm{L}$ in artificial seawater) from stock cultures, and stored at $-80^{\circ} \mathrm{C}$ in Zobell containing $15 \%$ glycerol (v/v). After a few days, one colony was grown at $22^{\circ} \mathrm{C}$ for $20 \mathrm{~h}$ in Zobell broth, with constant shaking at $40 \mathrm{rpm}$ (Rotator SB3; Stuart). The cells were centrifuged at 3,200 g for 10 min, the supernatant discarded and the resulting pellet resuspended in SASW to obtain an OD600 $\mathrm{nm}=1$. Purity and concentration of all suspensions were checked by plating, corresponding to $1 \times 10^{9}$ bacteria/ml, except for $V$. aestuarianus, for which it corresponded to $5 \times 10^{8} \mathrm{bacteria} / \mathrm{ml}$.

For a bath protocol at larvae stage, bacteria were directly diluted in seawater containing larvae to reach a final concentration of $10^{5}$ bacteria $\mathrm{ml}^{-1}$.

For bath protocol at spat stage, bacteria were first injected in muscle of $\mathrm{MgCl}_{2}$ anesthetized oysters $(15$ oysters/strain with $100 \mu 1$ of bacterial suspensions (DO600nm=1)). Those oysters were conserved in $3 \mathrm{~L}$ of UV-treated, filtered and aerated seawater for $24 \mathrm{~h}$. Contaminated seawater surrounding oysters was diluted $1 / 20$ in fresh UV-treated seawater, corresponding to 2 to $5 \times 10^{5}$ freshly shed bacteria $\mathrm{ml}^{-1}$. Bacterial viability and concentration were checked by plating and qPCR (Pollock et al., 2010; Saulnier et al., 2017; Travers et al., 2014). 
Bacterial isolates used here (Table 2) are already recognized as oyster pathogens and were clearly affiliated to the different Vibrio species. However, we also used a new $V$. neptunius isolate (09-123_1T2), identified here through 16S rDNA sequencing (GenBank number MT298104) and the targeted PCR designed by Lago et al. (2009).

\subsection{Experimental infection}

Five experimental infections were carried out for all families and wild stocks. Two occurred at the larval stage, trials Larval 1 (size $100 \mu \mathrm{m}$ ) and Larval 2 (size $150 \mu \mathrm{m}$ ); two at the spat stage, trials Spat 1 (size $5 \mathrm{~mm}$ ) and Spat 2 (size $5 \mathrm{~mm}$ ); and one at the juvenile size (size $50-60 \mathrm{~mm}$, 20g) (Table 3).

\subsubsection{Experimental infection with OsHV-1}

For each experimental infection, the bath method with contaminated seawater was used. For the larval stage, six-well plates were used using three wells per family and wild stock. Each well contained $5 \mathrm{ml}$ of contaminated seawater and approximately 100 larvae per well (+/- 30\%) (Table 3). Similarly, three wells per family and wild stock were used as controls using seawater that was filtered and UV-treated $(40 \mathrm{mj} / \mathrm{cm} 2)$. As a plate contained six wells, no plates contained both contaminated and control conditions, to limit unintentional contamination of the control. Plates were stored in an incubator at $20^{\circ} \mathrm{C}$, without movement, air bubbling and food. Mortality was recorded at days 2, 5 and 7 post-infection by placing the six-well plate under a binocular magnifier and by counting dead and live individuals for the first 30 larvae observed. For the spat stage, similar protocols were used with the exception that six wells were used per family and wild stock, containing 5 spat each $(2-10 \mathrm{~mm})$ in $10 \mathrm{ml}$ of contaminated seawater or filtered and UV-treated seawater (Table 3). Mortality was counted at days 4 and 7 post infection for the first challenge, and at days 5 and 7 for the second. At days 4 and 5, dead oysters were removed from the wells. 
Finally, three tanks were used per family and wild stock each containing 10 juveniles in 3 liters of contaminated seawater with aeration (Table 3). Mortality was recorded daily until day 7 postinfection, and dead oysters were removed each day. For the control, only one tank per family was used.

2.5.2. Experimental infection with several pathogenic strains of Vibrio in C. gigas Bacteria were grown on Zobell agar (peptone $4 \mathrm{~g} / \mathrm{L}$, yeast extract $1 \mathrm{~g} / \mathrm{L}$, Tris buffer $0.5 \mathrm{~g} / \mathrm{L}$ in artificial seawater) from stock cultures, stored at $-80^{\circ} \mathrm{C}$ in Zobell containing $15 \%$ glycerol (v/v). The same protocols as described above with OsHV-1 were also used for each of the following bacteria (Table 2): V. aestuarianus 02/041, V. coralliilyticus 06/210, V. crassostreae J2-9, V. harveyi 08/076_3T1, V. tasmaniensis LGP32, V. neptunius 09/123 1T2, and V. europaeus 07/118 T2 with some exceptions for the juvenile stage. Initially, all those pathogens were tested through an immersion of larvae containing $1 \times 10^{5}$ cultured bacteria $\mathrm{ml}^{-1}$. Immersion of spat was realized using contaminated seawater containing $2-5 \times 10^{5}$ of freshly shed bacteria, as previously described in Parizadeh et al. (2018).

Next, all families and wild stocks were also challenged at the juvenile stage by intramuscular injection with the different bacteria plus $V$. chagasii 8T1-3 (Table 3), with only 2 replicates per family and wild stock (Table 3). For each pathogen except for V. aestuarianus 02/041, oysters were directly injected with $50 \mu \mathrm{l}$ of a bacterial suspension into the adductor muscle, and mortality was recorded daily until day 3 post-injection. Dead oysters were removed daily. For $V$. aestuarianus, injection can lead to high mortality regardless of the level of selection for OsHV-1 resistance in C. gigas (Azéma et al., 2015). Thus, families and wild controls were tested using an experimental infection by cohabitation with naïve oysters injected with $V$. aestuarianus. After intramuscular injection of donor oysters, as described above, the injected oysters were transferred into 10-L tanks for $24 \mathrm{~h}$. In the second step, a ratio of $3 \mathrm{~g}$ of injected 
oysters (with the shell) per $3 \mathrm{~L}$ of sea water was used. Thus, the injected oysters were placed for $48 \mathrm{~h}$ in contact with the one family or control using two 5 liters tanks filled with 3 liters of filtered and UV-treated seawater and maintained at $21^{\circ} \mathrm{C}$ with adequate aeration and without adding food. Mortality was recorded daily until day 13 post-infection, the moribund oysters being removed daily. Finally, and similarly to V. aestuarianus, and in addition to the evaluation throughout injection, cohabitation was also done for $V$. coralliilyticus $06 / 210$, as well as for $V$. europaeus $07 / 118 \mathrm{~T} 2$, and mortality was recorded daily for seven days.

\subsection{Mortality data analyses}

All statistics were performed using $\mathrm{SAS}^{\circledR} 9.4$ software (Cary, NC, USA). Mortality was analyzed at endpoint, i.e., at day 7 for trials at the larval and spat stages, while at the juvenile stage, it was at day 7 for OsHV-1, day 13 for $V$. aestuarianus and day 3 for the other bacteria which were injected. Mortality was analyzed by a binomial logistic regression throughout the GLIMMIX procedure.

Due to some mortality for the control in the larval challenges, a first approach tested difference in mortality of C. gigas between the control and each of the pathogens for each trial. A second approach tested difference in mortality of $C$. gigas among pathogens within stage and trial.

Then, as OsHV-1 was tested using a bath infection protocol from larvae to juvenile, a first model tested the fixed factor stage (larvae, spat, and juvenile) at day 7. Then, mortality was analyzed within stage. For the larval and spat stages, two trials were used per stage. The models tested as fixed factors: trial (Larval 1 and 2 or Spat 1 and 2), oyster groups (families F1 to F9 and the three wild stocks), and their interactions, as well as the random factor replicates nested within trial and oyster group: 
$\operatorname{logit}\left(\pi_{\mathrm{ijk}}\right)=\mu+\operatorname{trial}_{i}+\operatorname{oyster}_{\operatorname{group}_{j}}+\left(\operatorname{trial}_{i} \mathrm{x} \text { oyster group }\right)_{i j}+$ replicate $_{\mathrm{k}(i j)}$

where $\pi_{\mathrm{ijk}}$ is the probability of the mortality at day 7 for oyster of the ith trial (Larval 1 vs Larval 2 or Spat 1 vs Spat 2) for the $j$ th oyster group (families F1 to F9 and the three wild stocks) at the $k$ th replicate ( 1 to 3 for larvae and 1 to 6 for spat), and $\mu$ the intercept.

At the juvenile stage, all factors including trial were removed from the analyses.

For bacteria, mortality was analyzed among oyster groups within trial, but only for bacterial strain inducing significantly higher mortality than control.

Finally, correlation of the mortality at endpoint was calculated between OsHV-1 or $V$. aestuarianus at the juvenile stage and each of the other pathogens tested within trial and within stage, to determine if selection applied for the families could have an impact on the resistance or susceptibility to other pathogens tested in this study.

\section{Results}

\subsection{Controls}

Controls showed no mortality at the spat and juvenile stages. At the larval stage, the mean mortality was $11 \%$ and $5 \%$ for the first and second trials, respectively (Fig. 1). In detail, all families had low mortality for the first larval trial, ranging from 0 to $28 \%$, while no mortality was observed for wild stocks (Table 4). For the second larval trial, mortality was only observed for the F2 family (59\%) and the F8 family (2\%) (Table 4).

3.2. Comparison of mortality of C. gigas among pathogens in larvae, spat and juveniles For the first larval trial, mean mortality among oyster groups was significantly different among pathogens $(\mathrm{P}<0.0001)$ with moderate mortality for OsHV-1 $(47 \%)$, intermediate for $V$. 
neptunius (28\%), V. coralliilyticus (26\%), V. europaeus (25\%), V. crassostreae (20\%), V. tasmaniensis (18\%), V. harveyi (14\%), and low mortality for larvae exposed to V. aestuarianus (1\%). Larvae exposed to $V$. harveyi had similar mortality $(14 \%)$ to controls $(\mathrm{P}=0.06)$, those exposed to V. aestuarianus had significant lower mortality $(1 \%)$ than controls $(\mathrm{P}<0.0001)$, while the other pathogens induced higher mortality than controls $(\mathrm{P}<0.0001)$.

For the second larval trial, significant differences in mortality among pathogens were also found, with the highest mortality for larvae exposed to OsHV-1 (71\%), intermediate for $V$. coralliilyticus (44\%), and the lowest for the other pathogens $(<7 \%)(\mathrm{P}<0.0001)$. Again, mortality of larvae exposed to V. aestuarianus was significantly lower (3\%) than observed for controls $(\mathrm{P}=0.04)$, while those exposed to OsHV-1 or $\mathrm{V}$. coralliilyticus had significant higher mortality than controls $(\mathrm{P}<0.0001)$. No difference in mortality from the control was observed for $V$. crassostreae (7\%), V. tasmaniensis (5\%), V.neptunius (4\%), V. europaeus (3\%), and V. harveyi $(4 \%)(\mathrm{P}>0.05)$.

For spat, no mortality of $C$. gigas was reported for any bacteria challenge using a bath method. Only OsHV-1 was able to induce mortality for both trials, $67 \%$ and $68 \%$ respectively.

At the juvenile stage, all pathogens induced mortality with high variation among those tested by injection. The mean mortality among oyster groups was $10 \%$ for $V$. chagasii, $18 \%$ for $V$. harveyi, $26 \%$ for $V$. crassostreae, $44 \%$ for $V$. tasmaniensis, $80 \%$ for $V$. neptunius, $88 \%$ for $V$. europaeus and $94 \%$ for V. coralliilyticus (Fig. 2). Moderate mortality was observed for OsHV1 using bath (50\%) and $V$. aestuarianus using cohabitation (44\%) (Fig. 2). Mortality was significantly different among pathogens $(\mathrm{P}<0.0001)$. Finally, no mortality was observed for the cohabitation methods using V. coralliilyticus and V. europaeus.

3.3. Comparison among oyster groups for experimental infections by OsHV-1 
Mean mortality among groups and trials was not significantly different between the larval (59\%) and spat $(68 \%)$ stages $(\mathrm{P}=0.93)$, while it was significantly lower at the juvenile stage $(50 \%)(\mathrm{P}<0.05)$. Mean mortality between trials or replicates per oyster group and per stage are reported in Fig. 3.

For the larval stage, interactions between the trial and the oyster groups were significant $(\mathrm{P}<0.01)$. Mean mortality among groups in trial $1(47 \%)$ was significant lower than in trial 2 (71\%). Nevertheless, for each trial, a significant difference in mortality was found among groups $(\mathrm{P}<0.001)$, with the lowest mortality for the F7 family $(14 \%)$, and the highest for the F6 family (89\%) (Fig. 3).

In contrast to the larval experiment, the interaction factor was not significant $(\mathrm{P}=0.32)$ at the spat stage as well as the trial factor $(\mathrm{P}=0.85)$, with similar mean mortality among groups in trials $1(67 \%)$ and $2(68 \%)$. Again, mortality was significantly different among groups $(\mathrm{P}<$ 0.0001) with the lowest mortality for the F7 family (15\%), and the highest for the F3 and F4 families (97\%) (Fig. 3).

At the juvenile stage, mortality was significantly different among groups ranging from $3 \%$ for the families F7 and F9 to 93\% for the families F3 and F4 (Fig. 3).

3.4. Comparison among oyster groups for experimental infections by bacteria

For the larval trials showing differences in mortality between the infected and the control conditions, mortality of each group is reported on Fig. 4. Significant differences in mortality among groups were observed for $V$. coralliilyticus in both trials, ranging from $1 \%$ for wild stock 1 to $80 \%$ for the family F2 in trial 1, and from $2 \%$ for the family F1 to $100 \%$ for wild stock 2 in trial 2 (Fig.4). Significant variation in mortality among oyster groups was also reported in 
trial 1 for V. crassostreae (from 1-87\%), V. tasmaniensis (0-69\%), V. neptunius (2-68\%), and V. europaeus (0-74\%) (Fig. 4) $(\mathrm{P}<0.05)$.

For juveniles, mortality varied among oyster groups when exposed to each pathogenic bacterial strain tested, ranging from $85-100 \%$ for $V$. coralliilyticus, $5-70 \%$ for $V$. crassostreae, $0-75 \%$ for $V$. tasmaniensis, $60-95 \%$ for V.neptunius, $65-100 \%$ for $V$. europaeus, $0-40 \%$ for $V$. harveyi, 0-30\% for V.chagasi, and $0-80 \%$ for V. aestuarianus (Fig. 5). Mortality was only significantly different among oyster groups for $V$. crassostreae $(\mathrm{P}=0.02)$ and $V$. aestuarianus $(\mathrm{P}<0.05)$.

3.5. Correlation of the mortality at endpoint between OsHV-1 or $V$. aestuarianus at the juvenile stage and each of the other pathogens

High and significant positive correlations were found between mortality due to OsHV-1 at the juvenile stage and the mortality due to OsHV-1 in trials Spat $1(\mathrm{r}=0.91$ and $P<0.01)$ and in Spat $2(\mathrm{r}=0.81$ and $P<0.01)($ Table 5). Similarly, correlation was significant between mortality due to OsHV-1 at the juvenile stage and mortality of juveniles when exposed to V. tasmaniensis ( $\mathrm{r}=0.70$ and $P<0.05)$. The other correlations between the mortality due to OsHV-1 in juvenile and the other pathogens tested from larvae to juvenile were not significant, nor was mortality observed in juveniles due to $V$. aestuarianus found to correlate significantly with any other mortality recorded across all experimental infections. 


\section{Discussion}

Mortality related to OsHV-1 among oyster families/groups has been broadly investigated worldwide in spat to adult C. gigas (Azéma et al., 2017b; Burge et al., 2006; Dégremont et al., 2010; Divilov et al., 2019; Gutierrez et al., 2020; Gutierrez et al., 2018; Hick et al., 2018; PradoAlvarez et al., 2016). A significant genetic basis for OsHV-1 resistance was demonstrated and a breeding program could enhance survival of spat as demonstrated by Dégremont et al. (2015b). Nevertheless, only one study deeply investigated the correlation in mortality of $C$. gigas families among spat, juveniles and adults (Azéma et al., 2017b). Concerning larvae, this stage is highly susceptible to OsHV-1 but most studies have used unselected oysters (Burge and Friedman, 2012; Le Deuff et al., 1994; Nagai and Nakamori, 2018). It would be of great importance to optimize breeding programs by testing oyster families as soon as the larval stage, in order to reduce the cost of the genetic evaluation. To our knowledge, only two studies investigated the effect of selection to enhance resistance to OsHV-1 at the larval stage. The first showed that parental origin did not have an effect on larvae mortality levels while it did at the spat stage (Prado-Alvarez et al., 2015). The second only used one resistant family and one control, and showed a difference in mortality between the two groups (Dégremont et al., 2016). Although mortality due to OsHV-1 was highly correlated between the spat and juvenile stages (Table 5), our study reveals that two of the resistant oyster families (F8 and F9) to OsHVlinfection at the juvenile stage had high mortality at the larval stage (Table 1) (Fig. 3) (Supplementary table 1). Only the F7 family showed high resistance to OsHV-1 at the larval stage in our conditions ( 6 well plate, 7 days, concentration $10^{4}$ OsHV-1 DNA copies $\mu \mathrm{L}^{-1}$ ). This family had the highest breeding value for OsHV-1 resistance at the spat and juvenile stages according to Azéma et al. (2017b), indicating that it could be possible to identify only the 
families with the highest potential of resistance to the infection by OsHV-1 as soon as the larval stage. The F7 family might be able to activate the antiviral response a few days after fertilization while it takes longer for other resistant families or that the viral dose was too high. Further experiments should be conducted to test the resistance of C. gigas larvae over several dilutions using the bath method to figure out the best dose to assess the relationship between the mortality at the larval stage and the mortality at the spat stage. The larval experiments developed in this study do represent a powerful approach for early detection of the best family and larval trials would be of a great interest for breeding programs that focus on OsHV-1 resistance.

Lower mortality in Larval 1 than in Larval 2, the interaction between trials and families at this stage, and some mortality observed for the controls revealed the importance to replicate experiments at this stage to certify the resistance to OsHV-1 of each oyster family/group tested, without performing another experimental infection at the spat stage. Indeed, only families showing high resistance in all trials during the larval stage should be selected for the breeding program, such as the F7 family, while family F3, which showed low mortality in Larval 1, had high mortality due to OsHV-1 for all other trials from larvaL to juvenile stages (Supplementary table 1). This difference might be in relation to the growth potential of the larvae that increased in older larvae by culling non-viable larvae and reducing the larval density in the larval tank before sampling them for the trial 2 .

As concerns $V$. aestuarianus, the bath methods used at the larval and spat stages failed to induce mortality at day 7 post-infection, while experimental infection by cohabitation managed to produce differences in mortality among families. As the susceptibility to $V$. aestuarianus increased with age and size (Azéma et al., 2016; Azéma et al., 2017b), it seems that testing $C$. gigas smaller than $5 \mathrm{~mm}$ in bath method is irrelevant.

Similarly, bath method failed to induce a single dead oyster for both trials at the spat stage for all other bacteria strains. We hypothesize that our experimental conditions were not well suited 
to the questions (dose, containers used, duration of the experiment) or that C. gigas spat are not susceptible to these pathogens at a size of $5 \mathrm{~mm}$. While cohabitation works for $V$. aestuarianus in juveniles, this method failed with $V$. coralliilyticus and $V$. europaeus. We can rule out a lack of susceptibility of juveniles to these pathogens, as high mortality was observed throughout injection (Fig. 2). Consequently, it is important to identify the best infection method to evaluate the susceptibility of oyster families, which should be adapted to the size of the oyster. Indeed, it will be challenging and time consuming to inject small spat, and impossible for larvae which are too small and fragile.

Beside OsHV-1, it appears that $V$. coralliilyticus induced the highest mortality in C. gigas larvae and juveniles among all bacteria tested (Fig.1-2). Whereas differences in mortality were evidenced among families and wild controls in both larval trials (Fig. 4), mortality was high $(>80 \%$ ) for all families at the juvenile stage (Fig. 5). Our study is the first to report (1) mortality caused by this bacterium in C. gigas juveniles and (2) variation among oyster groups in larvae, as previous experiments only test one batch of larvae and showed either high mortality (Richards et al., 2015), intermediate mortality (Kesarcodi-Watson et al., 2012) low mortality (Genard et al., 2013), or all three in a dose-dependent manner (Kim et al., 2019). In contrast, high variation in mortality was observed at the Larval 1 and juvenile trials for $V$. crassostreae, $V$. tasmaniensis, $V$. neptunius, and $V$. europaeus, and in a lesser extent for $V$. harveyi, $V$. chagasi (Fig. 4-5). Nevertheless, none of this mortality correlated to the two pathogens for which oysters were selected for (OsHV-1 or V. aestuarianus), except between $V$. tasmaniensis at the juvenile stage (Table 5). This bacterium was first isolated from oysters of the Marennes-Oléron Bay in 2001 and it is naturally present in the area where wild broodstocks were sampled to produce the families/wild controls, and where is located our hatchery and our facilities dedicated to the experimental infections. It could be supposed that resistance to this bacteria was co-selected for along with OsHV-1 at the juvenile stage. 


\section{Conclusions}

In summary, breeding programs focusing on dual resistance against OsHV-1 and $V$. aestuarianus could screen oyster families with very high resistance to the virus as soon as the larval stage by a bath method, and then select those showing the highest resistance to the bacteria using the cohabitation method at the juvenile stage. Nevertheless, such a strategy will exclude all families that develop resistance to the virus at older stages. Selection for disease resistance to OsHV-1 and $V$. aestuarianus seems not to negatively or positively impact the susceptibility to other major pathogens involved in mortality outbreaks in hatchery, nursery, or field settings (V. coralliilyticus, V. crassostreae, V. tasmaniensis, V. neptunius, V. europaeus, V. harveyi, V. chagasii). Finally, our study showed that larvae had the highest mortality when exposed to OsHV-1, followed by $V$. coralliilyticus for a bath method. Unfortunately, this experimental infection method was not adapted for all bacteria strains for spat $(5 \mathrm{~mm})$. Beside OsHV-1 and V. aestuarianus, high mortality was induced in juveniles by injecting $V$. coralliilyticus, V. europaeus, or V. neptunius. Variation in mortality observed among families/wild controls for these pathogens suggest differences in susceptibility among oysters, which could be a first step for breeding programs focusing on multiple pathogens in C. gigas.

\section{Acknowledgements}

We wish to thank the hatchery, nursery, genetic and pathology teams of the Laboratory of Genetics and Pathology, Ifremer La Tremblade and Ifremer Bouin for their assistance in oyster production, as well as Mélodie Chapat for her help for experimental infection. This study was 
funded by the H2020 project VIVALDI (Scientific basis and tools for preventing and mitigating farmed mollusk diseases; grant agreement 679589 of the European Commission).

\section{References}

Azéma, P., Travers, M.-A., Benabdelmouna, A., Dégremont, L., 2016. Single or dual experimental infections with Vibrio aestuarianus and OsHV-1 in diploid and triploid Crassostrea gigas at the spat, juvenile and adult stages. J. Invertebr. Pathol. 139, 92101.

Azéma, P., Maurouard, E., Lamy, J.-B., Dégremont, L., 2017a. The use of size and growing height to improve Crassostrea gigas farming and breeding techniques against OsHV-1. Aquaculture. 471, 121-129.

Azéma, P., Travers, M.-A., De Lorgeril, J., Tourbiez, D., Degremont, L., 2015. Can selection for resistance to OsHV-1 infection modify susceptibility to Vibrio aestuarianus infection in Crassostrea gigas? First insights from experimental challenges using primary and successive exposures. Vet. Res. 46, 139.

Azéma, P., Lamy, J.-B., Boudry, P., Renault, T., Travers, M.-A., Dégremont, L., 2017b. Genetic parameters of resistance to Vibrio aestuarianus, and OsHV-1 infections in the Pacific oyster, Crassostrea gigas, at three different life stages. Genet. Sel. Evol. 49, 23.

Barber, B.J., Davis, C.V., Crosby, M.A., 1998. Cultured oysters, Crassostrea virginica, genetically selected for fast growth in the Damariscotta River, Maine, are resistant to mortality caused by Juvenile Oyster Disease (JOD). J. Shellfish Res. 17, 1171-1175.

Bassini, L.N., Lhorente, J.P., Oyarzún, M., Bangera, R., Yáñez, J.M., Neira, R., 2019. Genetic parameters for Piscirickettsia salmonis resistance, sea lice (Caligus rogercresseyi) susceptibility and harvest weight in rainbow trout (Oncorhynchus mykiss). Aquaculture. 510, 276-282.

Bruto, M., James, A., Petton, B., Labreuche, Y., Chenivesse, S., Alunno-Bruscia, M., Polz, M.F., Le Roux, F., 2017. Vibrio crassostreae, a benign oyster colonizer turned into a pathogen after plasmid acquisition. Isme Journal. 11, 1043-1052.

Burge, C.A., Friedman, C.S., 2012. Quantifying Ostreid Herpesvirus (OsHV-1) Genome Copies and Expression during Transmission. Microb. Ecol. 63, 596-604.

Burge, C.A., Griffin, F.J., Friedman, C.S., 2006. Mortality and herpesvirus infections of the Pacific oyster Crassostrea gigas in Tomales Bay, California, USA. Dis. Aquat. Org. 72, 31-43.

Culloty, S.C., Cronin, M.A., Mulcahy, M.F., 2001. An investigation into the relative resistance of Irish flat oysters Ostrea edulis L. to the parasite Bonamia ostreae. Aquaculture. 199, 229-244.

Dégremont, L., 2011. Evidence of herpesvirus (OsHV-1) resistance in juvenile Crassostrea gigas selected for high resistance to the summer mortality phenomenon. Aquaculture. 317, 94-98.

Dégremont, L., Soletchnik, P., Boudry, P., 2010. Summer mortality of selected juvenile Pacific oyster Crassostrea gigas under laboratory conditions and in comparison with field performance. J. Shellfish Res. 29, 847-856.

Dégremont, L., Garcia, C., Allen Jr, S.K., 2015a. Genetic improvement for disease resistance in oysters: A review. J. Invertebr. Pathol. 131, 226-241. 
Dégremont, L., Nourry, M., Maurouard, E., 2015b. Mass selection for survival and resistance to OsHV-1 infection in Crassostrea gigas spat in field conditions: response to selection after four generations. Aquaculture. 446, 111-121.

Dégremont, L., Ernande, B., Bedier, E., Boudry, P., 2007. Summer mortality of hatcheryproduced Pacific oyster spat (Crassostrea gigas). I. Estimation of genetic parameters for survival and growth. Aquaculture. 262, 41-53.

Dégremont, L., Morga, B., Trancart, S., Pépin, J.F., 2016. Resistance to OsHV-1 infection in Crassostrea gigas larvae. Frontiers in Marine Science. 3.

Dégremont, L., Bédier, E., Soletchnik, P., Ropert, M., Huvet, A., Moal, J., Samain, J.F., Boudry, P., 2005. Relative importance of family, site, and field placement timing on survival, growth, and yield of hatchery-produced Pacific oyster spat (Crassostrea gigas). Aquaculture. 249, 213-229.

Divilov, K., Schoolfield, B., Morga, B., Dégremont, L., Burge, C.A., Mancilla Cortez, D., Friedman, C.S., Fleener, G.B., Dumbauld, B.R., Langdon, C., 2019. First evaluation of resistance to both a California OsHV-1 variant and a French OsHV-1 microvariant in Pacific oysters. BMC Genet. 20, 96.

Dove, M.C., Nell, J.A., McOrrie, S., O'Connor, W.A., 2013. Assessment of Qx and winter mortality disease resistance of mass selected Sydney rock oysters, Saccostrea glomerata (Gould, 1850), in the Hawkesbury River and Merimbula Lake, NSW Australia. J. Shellfish Res. 32, 681-687.

Dubert, J., Romalde, J.L., Spinard, E.J., Nelson, D.R., Gomez-Chiarri, M., Barja, J.L., 2016. Reclassification of the larval pathogen for marine bivalves Vibrio tubiashii subsp. europaeus as Vibrio europaeus sp. nov. Int. J. Syst. Evol. Microbiol. 66, 4791-4796.

Elston, R.A., Hasegawa, H., Humphrey, K.L., Polyak, I.K., Hase, C.C., 2008. Re-emergence of Vibrio tubiashii in bivalve shellfish aquaculture: severity, environmental drivers, geographic extent and management. Dis. Aquat. Org. 82, 119-134.

Frank-Lawale, A., Allen, S.K., Dégremont, L., 2014. Breeding and domestication of Eastern oyster (Crassostrea virginica) lines for culture in the mid-Atlantic, Usa: line development and mass selection for disease resistance. J. Shellfish Res. 33, 153-165.

Garnier, M., Labreuche, Y., Garcia, C., Robert, M., Nicolas, J.-L., 2007. Evidence for the involvement of pathogenic bacteria in summer mortalities of the Pacific oyster Crassostrea gigas. Microb. Ecol. 53, 187-196.

Gay, M., Berthe, F.C.J., Le Roux, F., 2004. Screening of Vibrio isolates to develop an experimental infection model in the Pacific oyster Crassostrea gigas. Dis. Aquat. Org. 59, 49-56.

Genard, B., Miner, P., Nicolas, J.-L., Moraga, D., Boudry, P., Pernet, F., Tremblay, R., 2013. Integrative study of physiological changes associated with bacterial infection in pacific oyster larvae. PLoS ONE. 8, e64534-e64534.

Gutierrez, A.P., Symonds, J., King, N., Steiner, K., Bean, T.P., Houston, R.D., 2020. Potential of genomic selection for improvement of resistance to ostreid herpesvirus in Pacific oyster (Crassostrea gigas). Anim. Genet. 51, 249-257.

Gutierrez, A.P., Bean, T.P., Hooper, C., Stenton, C.A., Sanders, M.B., Paley, R.K., Rastas, P., Bryrom, M., Matika, O., Houston, R.D., 2018. A genome-wide association study for host resistance to ostreid herpesvirus in Pacific oysters (Crassostrea gigas). G3: Genes $\mid$ Genomes $\mid$ Genetics. 8, 1273-1280.

Hick, P.M., Evans, O., Rubio, A., Dhand, N.K., Whittington, R.J., 2018. Both age and size influence susceptibility of Pacific oysters (Crassostrea gigas) to disease caused by Ostreid herpesvirus-1 (OsHV-1) in replicated field and laboratory experiments. Aquaculture. 489, 110-120. 
Kesarcodi-Watson, A., Miner, P., Nicolas, J.-L., Robert, R., 2012. Protective effect of four potential probiotics against pathogen-challenge of the larvae of three bivalves: Pacific oyster (Crassostrea gigas), flat oyster (Ostrea edulis) and scallop (Pecten maximus). Aquaculture. 344-349, 29-34.

Kim, H.J., Jun, J.W., Giri, S.S., Chi, C., Yun, S., Kim, S.G., Kim, S.W., Kang, J.W., Han, S.J., Kwon, J., Oh, W.T., Park, S.C., 2019. Application of the bacteriophage pVco-14 to prevent Vibrio coralliilyticus infection in Pacific oyster (Crassostrea gigas) larvae. J. Invertebr. Pathol. 167.

Lago, E.P., Nieto, T.P., Seguín, R.F., 2009. Fast detection of Vibrio species potentially pathogenic for mollusc. Vet. Microbiol. 139, 339-346.

Le Deuff, R.-M., Nicolas, J.-L., Renault, T., Cochennec, N., 1994. Experimental transmission of a Herpes-like virus to axenic larvae of Pacific oyster, Crassostrea gigas. Bull. Eur. Assoc. Fish Pathol. 14, 69-72.

Lemire, A., Goudenege, D., Versigny, T., Petton, B., Calteau, A., Labreuche, Y., Le Roux, F., 2015. Populations, not clones, are the unit of vibrio pathogenesis in naturally infected oysters. ISME J. 9, 1523-1531.

Mersni-Achour, R., Cheikh, Y.B., Pichereau, V., Doghri, I., Etien, C., Dégremont, L., Saulnier, D., Fruitier-Arnaudin, I., Travers, M.-A., 2015. Factors other than metalloprotease are required for full virulence of French Vibrio tubiashii isolates in oyster larvae. Microbiology. 161, 997-1007.

Naciri-Graven, Y., Martin, A.G., Baud, J.P., Renault, T., Gérard, A., 1998. Selecting the flat oyster Ostrea edulis (L.) for survival when infected with the parasite Bonamia ostreae. J. Exp. Mar. Biol. Ecol. 224, 91-107.

Nagai, T., Nakamori, M., 2018. Experimental infection of Ostreid Herpesvirus 1 (OsHV-1) JPType1, a Japanese variant, in Pacific oyster Crassostrea gigas larvae and spats. Fish Pathol. 53, 71-77.

Parizadeh, L., Tourbiez, D., Garcia, C., Haffner, P., Dégremont, L., Le Roux, F., Travers, M.A., 2018. Ecologically realistic model of infection for exploring the host damage caused by Vibrio aestuarianus. Environ. Microbiol. 20, 4343-4355.

Pollock, F.J., Morris, P.J., Willis, B.L., Bourne, D.G., 2010. Detection and Quantification of the Coral Pathogen Vibrio coralliilyticus by Real-Time PCR with TaqMan Fluorescent Probes. Appl. Environ. Microbiol. 76, 5282-5286.

Prado-Alvarez, M., Carlsson, J., Culloty, S.C., 2015. Experimental infection of Crassostrea gigas spat and larvae with different susceptibility to OsHV-1 mu var. J. Shellfish Res. 34, 671-672.

Prado-Alvarez, M., Darmody, G., Hutton, S., O'Reilly, A., Lynch, S.A., Culloty, S.C., 2016. Occurrence of OsHV-1 in Crassostrea gigas Cultured in Ireland during an Exceptionally Warm Summer. Selection of Less Susceptible Oysters. Frontiers in Physiology. 7.

Prado, S., Romalde, J.L., Montes, J., Barja, J.L., 2005. Pathogenic bacteria isolated from disease outbreaks in shellfish hatcheries. First description of Vibrio neptunius as an oyster pathogen. Dis. Aquat. Org. 67, 209-215.

Ragone Calvo, L.M.R., Calvo, G.W., Burreson, E.M., 2003. Dual disease resistance in a selectively bred eastern oyster, Crassostrea virginica, strain tested in Chesapeake Bay. Aquaculture. 220, 69-87.

Richards, G.P., Watson, M.A., Needleman, D.S., Church, K.M., Häse, C.C., 2015. Mortalities of Eastern and Pacific Oyster Larvae Caused by the Pathogens Vibrio coralliilyticus and Vibrio tubiashii. Appl. Environ. Microbiol. 81, 292-297.

Saulnier, D., De Decker, S., Tourbiez, D., Travers, M.A., 2017. Development of a duplex Taqman real-time PCR assay for rapid identification of Vibrio splendidus-related and V. aestuarianus strains from bacterial cultures. J. Microbiol. Methods. 140, 67-69. 
Saulnier, D., De Decker, S., Haffner, P., Cobret, L., Robert, M., Garcia, C., 2010. A large-scale epidemiological study to identify bacteria pathogenic to Pacific oyster Crassostrea gigas and correlation between virulence and metalloprotease-like activity. Microb. Ecol. 59, 787-798.

Sawabe, T., Ogura, Y., Matsumura, Y., Feng, G., Amin, A.R., Mino, S., Nakagawa, S., Sawabe, T., Kumar, R., Fukui, Y., Satomi, M., Matsushima, R., Thompson, F.L., Gomez-Gil, B., Christen, R., Maruyama, F., Kurokawa, K., Hayashi, T., 2013. Updating the Vibrio clades defined by multilocus sequence phylogeny: proposal of eight new clades, and the description of Vibrio tritonius sp. nov. Frontiers in Microbiology. 4, 414-414.

Schikorski, D., Renault, T., Saulnier, D., Faury, N., Moreau, P., Pepin, J.-F., 2011. Experimental infection of Pacific oyster Crassostrea gigas spat by ostreid herpesvirus 1: demonstration of oyster spat susceptibility. Vet. Res. 42, 27.

Silva, R.M.O., Evenhuis, J.P., Vallejo, R.L., Tsuruta, S., Wiens, G.D., Martin, K.E., Parsons, J.E., Palti, Y., Lourenco, D.A.L., Leeds, T.D., 2019. Variance and covariance estimates for resistance to bacterial cold water disease and columnaris disease in two rainbow trout breeding populations. J. Anim. Sci. 97, 1124-1132.

Travers, M.-A., Mersni Achour, R., Haffner, P., Tourbiez, D., Cassone, A.-L., Morga, B., Doghri, I., Garcia, C., Renault, T., Fruitier-Arnaudin, I., Saulnier, D., 2014. First description of French V. tubiashii strains pathogenic to mollusk: I. Characterization of isolates and detection during mortality events. J. Invertebr. Pathol. 123, 38-48.

$/ *$ Due to Endnote scripts, this will deleted in the final version, because the two followings

references appears only in Table 3 (Garnier et al., 2007; Lemire et al., 2015)*/ 


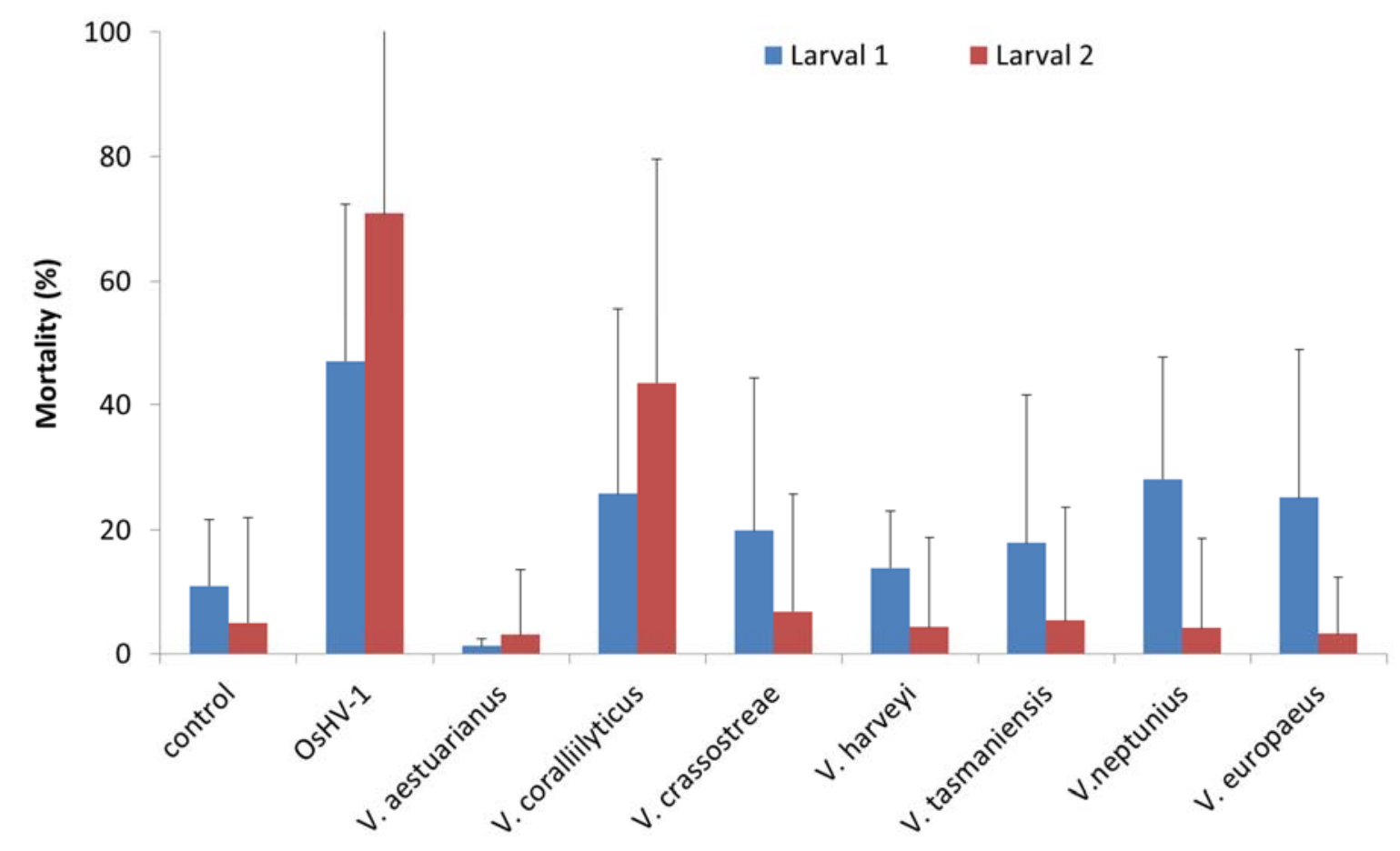

Fig. 1 Mean mortality (\% + SD among oyster families and wild stocks) for the control and each pathogen using bath method in C. gigas larvae.

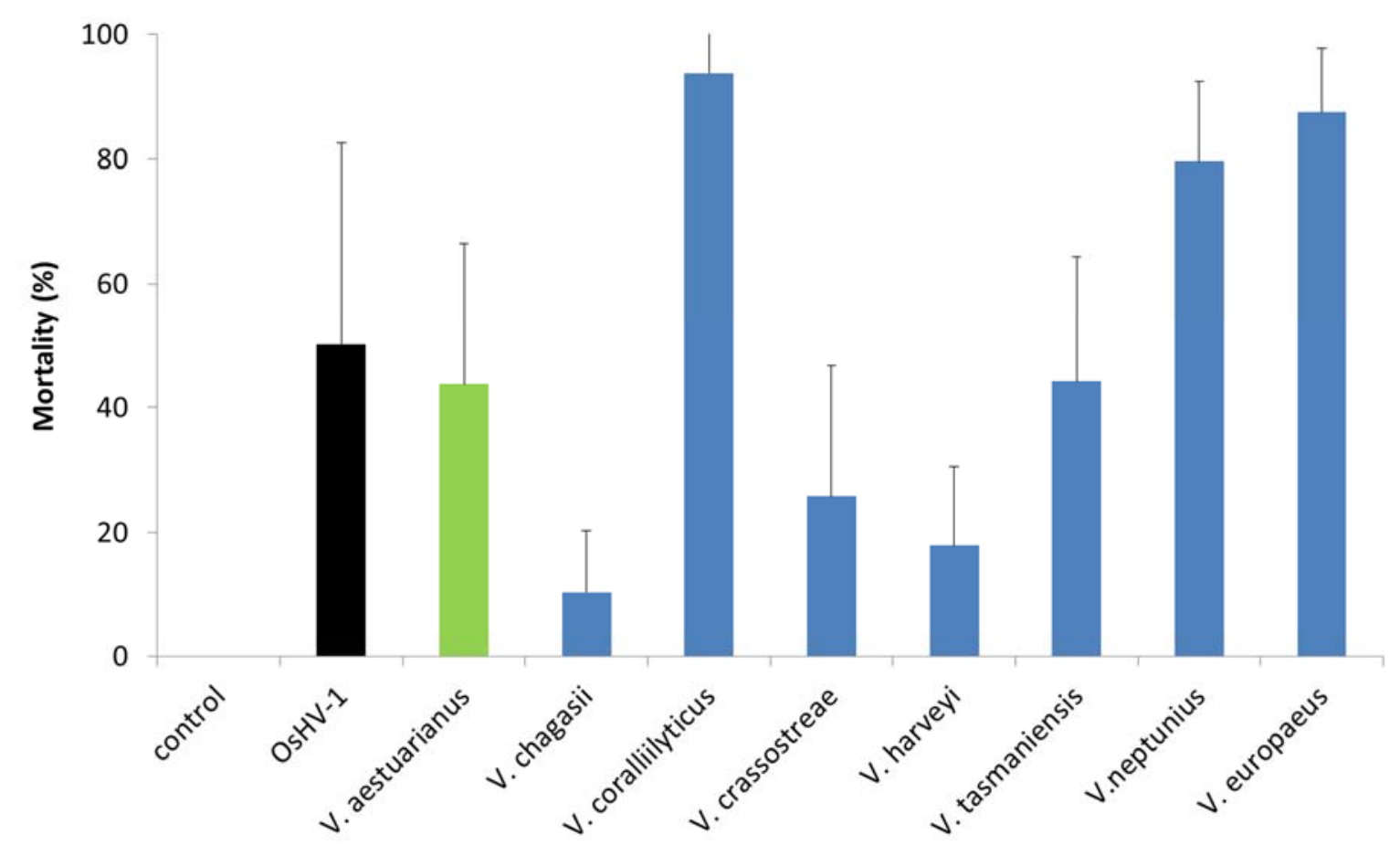


Fig. 2 Mean mortality (\% + SD among oyster families and wild stocks) for the control and each pathogen using bath method (in black), cohabitation method (in green), or injection (in blue) in $C$. gigas juvenile.

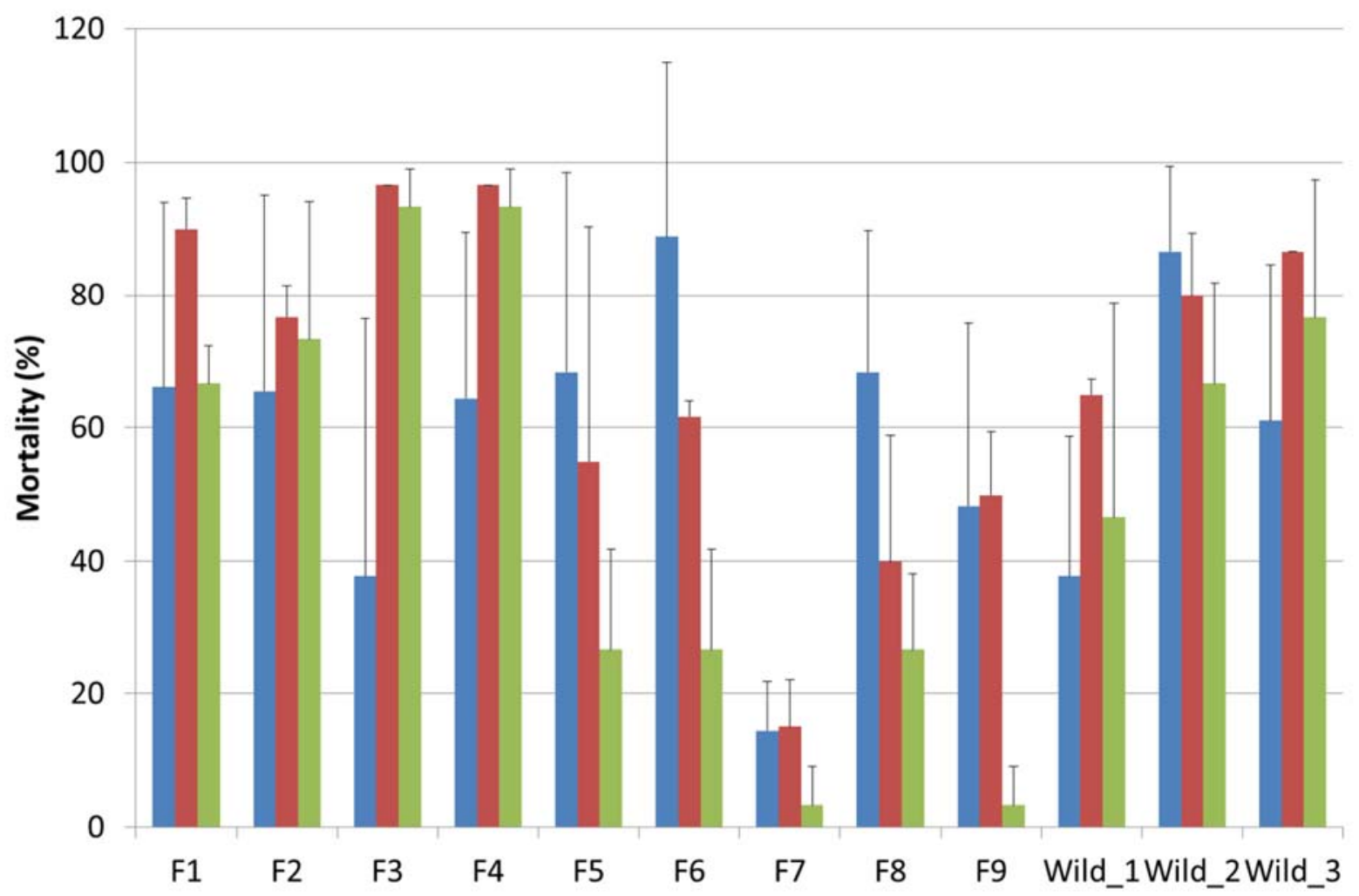

Figure 3: Mortality (\% + SD among trials within stage for the larval and spat trials, and among replicates for the juvenile stage) 7 days post-infection by OsHV-1 (bath method) for the nine families and the three wild stocks at the larval (in blue), spat (in red) and juvenile (in green) stages. 

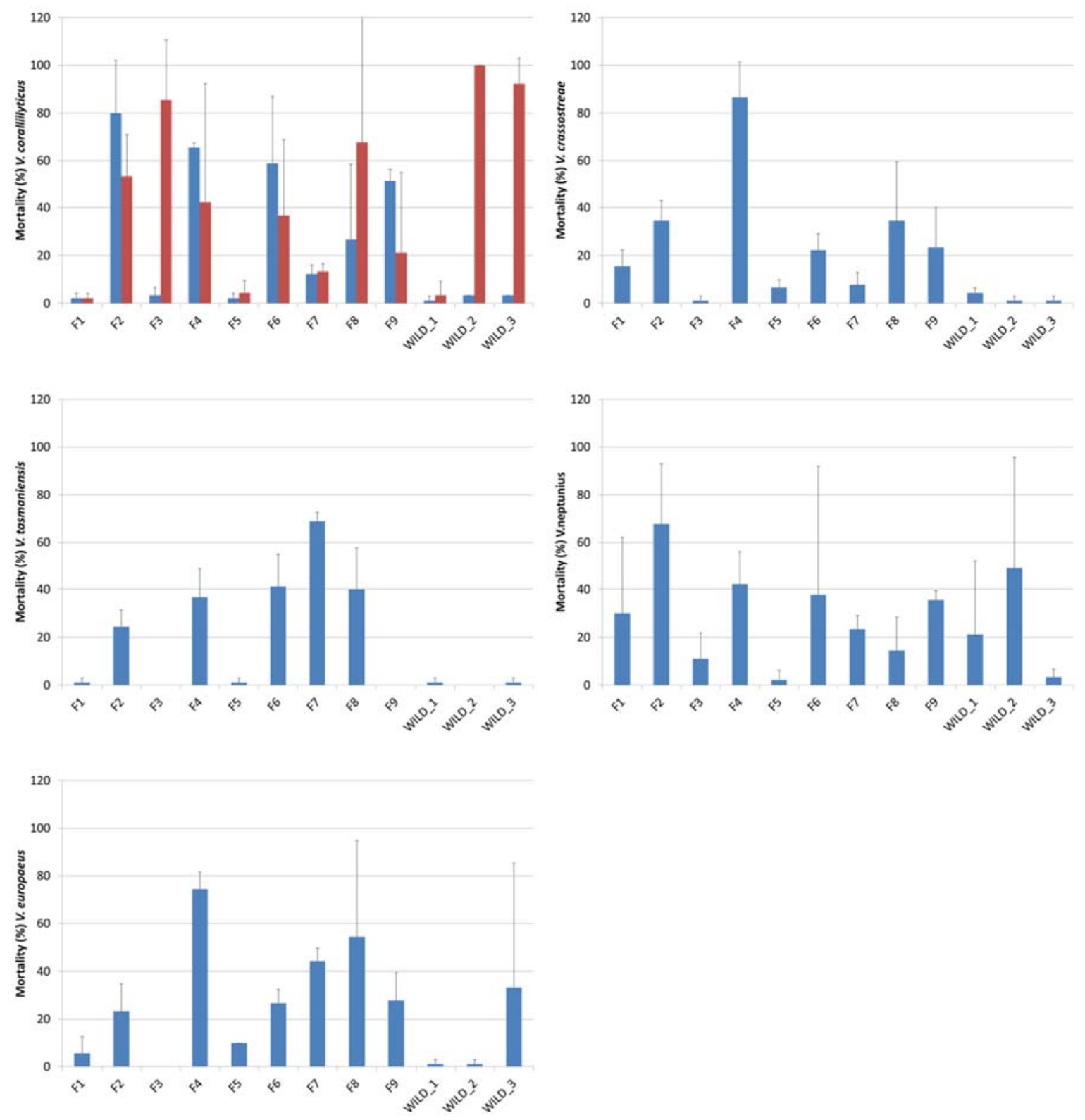

Figure 4: Mortality (\% + SD among replicates) 7 days post-infection by $V$. coralliilyticus, $V$.

crassostreae, $V$. tasmaniensis, V.neptunius, and $V$. europaeus for the nine families and the three wild stocks in Larval 1 (blue) and Larval 2 (in red) using a batch method. Due to the absence of difference in mortality between the control and experimental infection using bacteria, data are not showed for $V$. harveyi in both larval trials, and for Larval 2 except for V. coralliilyticus. 

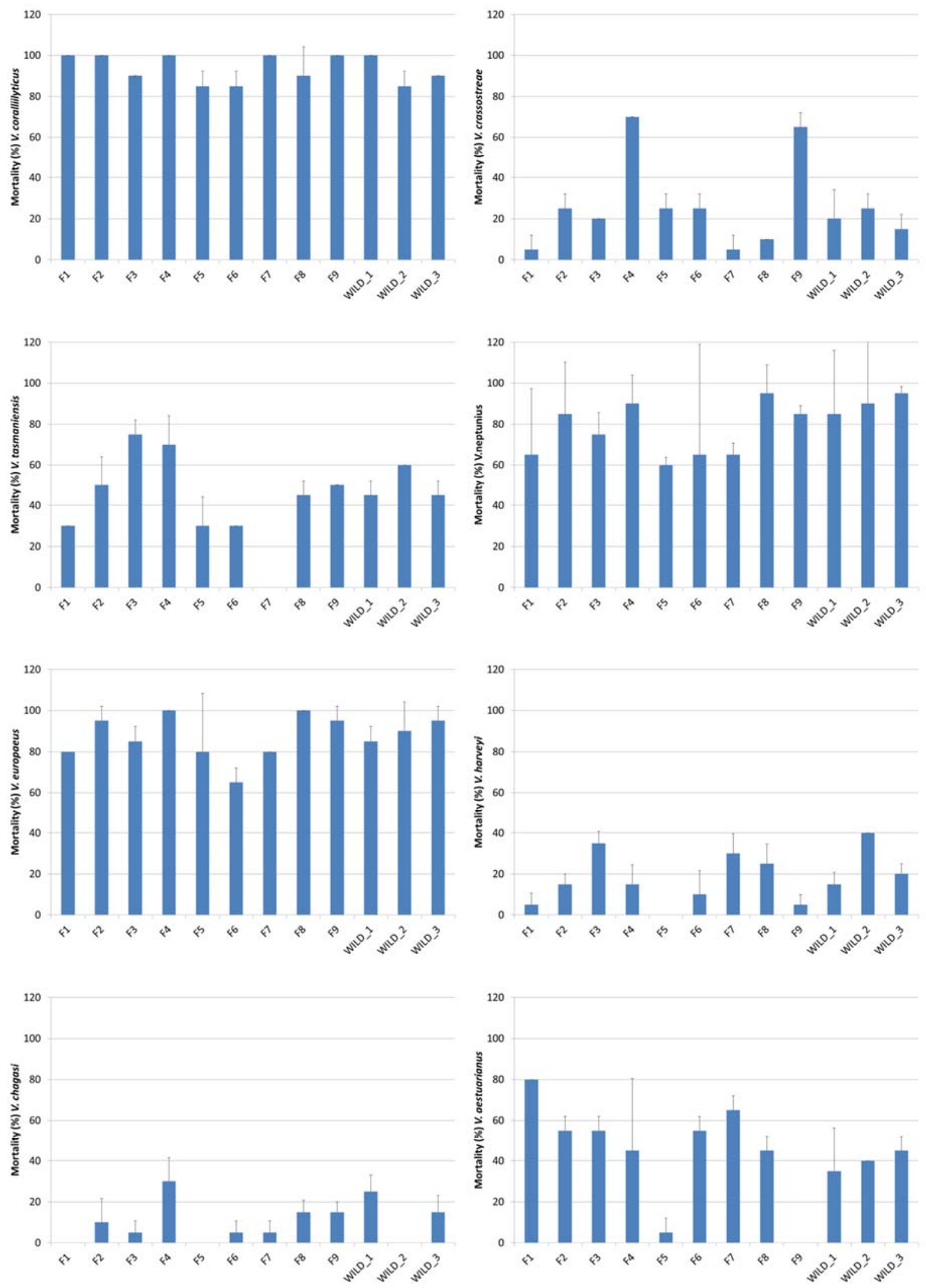

Figure 3: Mortality (\% + SD among replicates) 3 days post-injection by $V$. coralliilyticus, $V$. crassostreae, $V$. tasmaniensis, V.neptunius, V. europaeus, V. harveyi, V. chagasi, and 13 days post- 
infection by $V$. aestuarianus (cohabitation) for the nine families and the three wild stocks at the juvenile stage. 


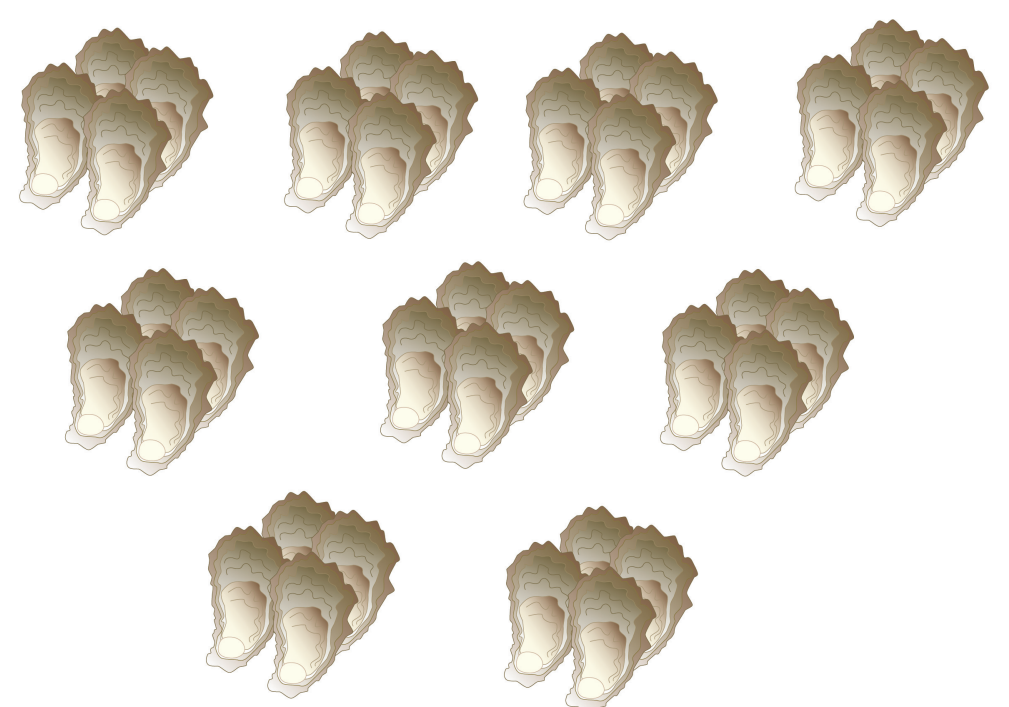

9 families with various levels of disease

3 wild families controls resistance to OsHV-1 and/or V. aestuarianus

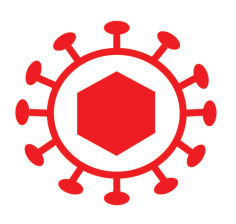

OsHV-1

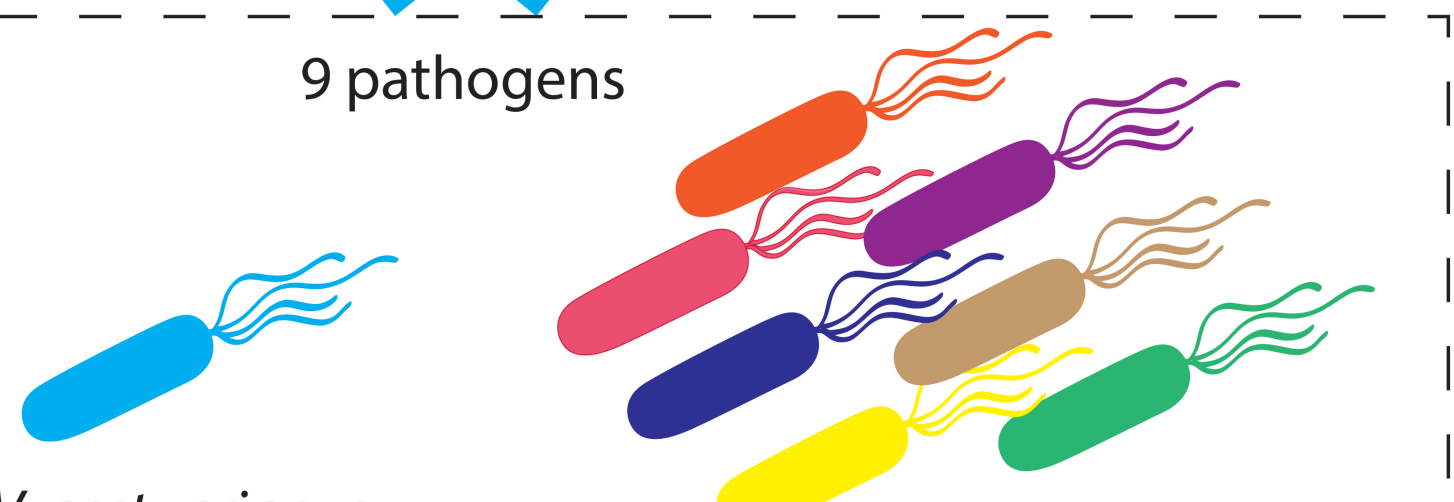

V. aestuarianus

7 others Vibrios.sp

3 life stages

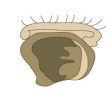

Larvae

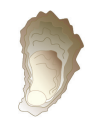

Spat

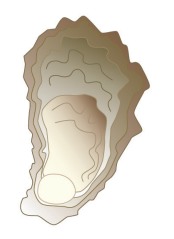

Juvenile

Optimization of breeding programs to enhance disease resistance and its impact on other relevant pathogens in C. gigas 
Table 1: Oyster families or origins

\begin{tabular}{|c|c|c|c|c|c|}
\hline \multirow[t]{2}{*}{ Broodstock $^{1}$} & \multirow[t]{2}{*}{ Generation $^{2}$} & \multirow{2}{*}{$\begin{array}{l}\text { Number } \\
\text { of parents }\end{array}$} & \multirow{2}{*}{$\begin{array}{l}\text { Inbreeding } \\
\text { rate } \mathrm{F}\end{array}$} & \multicolumn{2}{|c|}{ Susceptibility to ${ }^{3}$} \\
\hline & & & & $O s H V-1$ & $\begin{array}{l}\text { Vibrio } \\
\text { aestuarianus }\end{array}$ \\
\hline F1 & G1 & 17 & 0.25 & Susceptible & Susceptible \\
\hline F2 & G1 & 20 & 0.25 & Susceptible & Susceptible \\
\hline F3 & G1 & 18 & 0.25 & Susceptible & Moderate \\
\hline F4 & G1 & 18 & 0.25 & Susceptible & Moderate \\
\hline F5 & G1 & 10 & 0.25 & Susceptible & Resistant \\
\hline F6 & G1 & 12 & 0.25 & Moderate & Moderate \\
\hline F7 & G1 & 9 & 0.25 & Resistant & Susceptible \\
\hline F8 & G1 & 12 & 0.25 & Resistant & Moderate \\
\hline F9 & G1 & 18 & 0.25 & Resistant & Resistant \\
\hline Wild-1 & G0 & 30 & 0 & unknown & unknown \\
\hline Wild-2 & G0 & 11 & 0 & unknown & unknown \\
\hline Wild-3 & G0 & 20 & 0 & unknown & unknown \\
\hline
\end{tabular}

${ }^{1}$ Each G0 family (F1 to F9) was initially produced by mating one female and one male

${ }^{2} \mathrm{G}$ for generation

${ }^{3}$ from experimental infection occurring at the juvenile stage 
Table 2: List of bacterial strains used

\begin{tabular}{|c|c|c|c|c|c|}
\hline Species & Strain & Sample origin & $\begin{array}{l}\text { Sampling } \\
\text { location }\end{array}$ & $\begin{array}{l}\text { Sampling } \\
\text { date }\end{array}$ & Identification \\
\hline V. aestuarianus & $02-041$ & Diseased cupped oysters & France & 2002 & Garnier et al. 2007 \\
\hline V. chagasii & $8 \mathrm{~T} 1 \_3$ & Diseased cupped oysters & France & 2014 & Bruto et al. 2017 \\
\hline V. crassostreae & $J 2-9$ & Diseased cupped oysters & France & 2013 & Lemire et al. 2015 \\
\hline V. coralliilyticus & $06-210$ & Diseased cupped oysters & France & 2006 & Travers et al. 2014 \\
\hline V. europaeus & 07-118_T1 & Diseased cupped oysters & France & 2007 & Travers et al. 2014 \\
\hline V. harveyi & 08/076_3T1 & Diseased cupped oysters & France & 2008 & Saulnier et al. 2010 \\
\hline V. neptunius & 09-123_1T2 & Diseased cupped oysters & France & 2009 & This publication \\
\hline V. tasmaniensis & LGP32 & Diseased cupped oysters & France & 2001 & Gay et al. 2004 \\
\hline
\end{tabular}


Table 3: Experimental infections conducted for all families and wild stocks

\begin{tabular}{|c|c|c|c|c|c|}
\hline Date & $03 / 30 / 16$ & 04/01/16 & $05 / 26 / 16$ & $06 / 02 / 16$ & $12 / 16$ and $01 / 17$ \\
\hline Stage and trial number & Larval 1 & Larval 2 & Spat 1 & Spat 2 & Juvenile $^{1}$ \\
\hline Size & $100 \mu \mathrm{m}$ & $150 \mu \mathrm{m}$ & $5 \mathrm{~mm}$ & $5 \mathrm{~mm}$ & $20 \mathrm{~g} \sim 50-60 \mathrm{~mm}$ \\
\hline OsHV-1 & bath & bath & bath & bath & bath \\
\hline V. aestuarianus 02/041 & bath & bath & bath & bath & cohabitation \\
\hline V. coralliilyticus $06 / 210$ & bath & bath & bath & bath & injection and cohabitation \\
\hline V. crassostreae J2-9 & bath & bath & bath & bath & injection \\
\hline V. harveyi 08/076_3T1 & bath & bath & bath & bath & injection \\
\hline V. tasmaniensis LGP32 & bath & bath & bath & bath & injection \\
\hline V.neptunius 09/123 1T2 & bath & bath & bath & bath & injection \\
\hline $\begin{array}{l}\text { V.europaeus } 07 / 118 \text { T2 } \\
\text { V. chagasii } 8 T 1-3\end{array}$ & bath & bath & bath & bath & $\begin{array}{l}\text { injection and cohabitation } \\
\text { injection }\end{array}$ \\
\hline Container & $\begin{array}{l}\text { 6-well } \\
\text { plate }\end{array}$ & $\begin{array}{l}\text { 6-well } \\
\text { plate }\end{array}$ & $\begin{array}{l}\text { 6-well } \\
\text { plate }\end{array}$ & $\begin{array}{l}\text { 6-well } \\
\text { plate }\end{array}$ & 5 I tank \\
\hline Number of replicates ${ }^{2}$ & 3 & 3 & 6 & 6 & 3 or 2 \\
\hline $\begin{array}{l}\text { Number of individual per } \\
\text { replicate }\end{array}$ & $100^{3}$ & $100^{3}$ & 5 & 5 & 10 \\
\hline
\end{tabular}

${ }^{1} 3$ replicates for OsHV-1, and 2 for the other pathogens

${ }^{2}$ The number of replicates is given per family or wild stock and per pathogen

${ }^{3}$ This number could vary $+/-30 \%$, as it cannot be possible to put the exact number of larvae due to their small size. Mortality was recorded from the first 30 larvae (dead+alive) observed using a binocular magnifier. 
Table 4: Mortality for the controls at each experimental infection

\begin{tabular}{cccccc}
\hline Family/wild stock & Larval_1 & Larval_2 & Spat_1 & Spat_2 & Juvenile \\
\hline F1 & $1.1 \pm 1.9$ & $0 \pm 0$ & $0 \pm 0$ & $0 \pm 0$ & $0 \pm 0$ \\
F2 & $27.7 \pm 11.7$ & $58.8 \pm 8.9$ & $0 \pm 0$ & $0 \pm 0$ & $0 \pm 0$ \\
F3 & $2.2 \pm 1.9$ & $0 \pm 0$ & $0 \pm 0$ & $0 \pm 0$ & $0 \pm 0$ \\
F4 & $22.2 \pm 12.6$ & $0 \pm 0$ & $0 \pm 0$ & $0 \pm 0$ & $0 \pm 0$ \\
F5 & $3.3 \pm 3.3$ & $0 \pm 0$ & $0 \pm 0$ & $0 \pm 0$ & $0 \pm 0$ \\
F6 & $21.1 \pm 3.8$ & $0 \pm 0$ & $0 \pm 0$ & $0 \pm 0$ & $0 \pm 0$ \\
F7 & $21.1 \pm 8.4$ & $0 \pm 0$ & $0 \pm 0$ & $0 \pm 0$ & $0 \pm 0$ \\
F8 & $16.6 \pm 8.8$ & $2.2 \pm 1.9$ & $0 \pm 0$ & $0 \pm 0$ & $0 \pm 0$ \\
F9 & $16.6 \pm 15.2$ & $0 \pm 0$ & $0 \pm 0$ & $0 \pm 0$ & $0 \pm 0$ \\
Wild_1 & $0 \pm 0$ & $0 \pm 0$ & $0 \pm 0$ & $0 \pm 0$ & $0 \pm 0$ \\
Wild_2 & $0 \pm 0$ & $0 \pm 0$ & $0 \pm 0$ & $0 \pm 0$ & $0 \pm 0$ \\
Wild_3 & $0 \pm 0$ & $0 \pm 0$ & $0 \pm 0$ & $0 \pm 0$ & $0 \pm 0$ \\
\hline
\end{tabular}


Table 5: Correlations between the mortality at endpoint by OsHV-1 or V. aestuarianus at the juvenile stage and each of the other pathogens (sorted by ascending $P$ value)

\begin{tabular}{|c|c|c|c|c|c|}
\hline \multicolumn{4}{|c|}{ OsHV-1 juvenile } & \multicolumn{2}{|c|}{ V. aestuarianus juvenile } \\
\hline & $r$ & $\mathrm{P}$ & & $r$ & $P$ \\
\hline OsHV-1_spat1 & 0.91 & $<.0001$ & V_crass_juv & -0.55 & 0.06 \\
\hline OsHV-1_spat2 & 0.81 & $<0.01$ & V_aestu_lar1 & 0.45 & 0.15 \\
\hline V_tasm_juv & 0.70 & $<0.05$ & OsHV-1_spat1 & 0.43 & 0.17 \\
\hline V_cora_lar2 & 0.52 & 0.09 & V_tasm_lar1 & 0.39 & 0.22 \\
\hline V_har_lar1 & -0.43 & 0.16 & OsHV-1_juv & 0.38 & 0.23 \\
\hline V_aestu_lar1 & -0.39 & 0.21 & V_har_juv & 0.34 & 0.28 \\
\hline V_aestu_juv & 0.38 & 0.23 & V_euro_juv & -0.24 & 0.45 \\
\hline V_tasm_lar1 & -0.36 & 0.25 & V_cora_juv & 0.21 & 0.52 \\
\hline V_nept_juv & 0.34 & 0.28 & V_nept_lar1 & 0.20 & 0.53 \\
\hline V_euro_juv & 0.31 & 0.33 & V_crass_lar2 & 0.19 & 0.56 \\
\hline V_har_juv & 0.29 & 0.36 & V_tasm_juv & -0.18 & 0.57 \\
\hline V_euro_lar2 & 0.23 & 0.47 & V_euro_lar2 & 0.16 & 0.61 \\
\hline V_tasm_lar2 & 0.22 & 0.48 & V_har_lar2 & 0.16 & 0.62 \\
\hline V_aestu_lar2 & 0.22 & 0.48 & V_tasm_lar2 & 0.16 & 0.63 \\
\hline V_nept_lar2 & 0.22 & 0.49 & V_nept_juv & -0.16 & 0.63 \\
\hline V_crass_lar1 & 0.22 & 0.49 & V_nept_lar2 & 0.16 & 0.63 \\
\hline V_har_lar2 & 0.21 & 0.50 & V_aestu_lar2 & 0.16 & 0.63 \\
\hline V_chaga_juv & 0.21 & 0.52 & V_chaga_juv & -0.15 & 0.64 \\
\hline OsHV-1_lar2 & 0.19 & 0.55 & V_cora_lar2 & 0.12 & 0.71 \\
\hline V_crass_lar2 & 0.19 & 0.56 & OsHV-1_lar2 & -0.10 & 0.76 \\
\hline V_nept_lar1 & 0.16 & 0.62 & V_har_lar1 & -0.08 & 0.82 \\
\hline OsHV-1_lar1 & 0.13 & 0.68 & V_euro_lar1 & 0.05 & 0.87 \\
\hline V_euro_lar1 & -0.09 & 0.78 & V_cora_lar1 & -0.04 & 0.91 \\
\hline V_crass_juv & 0.08 & 0.81 & V_crass_lar1 & 0.04 & 0.91 \\
\hline V_cora_juv & 0.01 & 0.98 & OsHV-1_spat2 & -0.03 & 0.94 \\
\hline V_cora_lar1 & -0.01 & 0.99 & OsHV-1_lar1 & 0.01 & 0.99 \\
\hline
\end{tabular}

lar1, lar2, spat1, spat2, and juv for larval 1, larval 2, spat1, spat 2, and juvenile trials, respectively. 
Supplementary Table S1: Mean mortality ( \pm SD among replicates) for each family and wild stock for the five experimental infections by OsHV-1 and among experimental infections

\begin{tabular}{|c|c|c|c|c|c|c|}
\hline \multicolumn{7}{|c|}{ OsHV-1 challenge } \\
\hline & Larval_1 & Larval_2 & Spat_1 & Spat_2 & Juvenile & Mean \\
\hline F1 & $32.2 \pm 30.9$ & $100 \pm 0.0$ & $93.3 \pm 10.3$ & $86.6 \pm 16.3$ & $66.6 \pm 5.8$ & $75.7 \pm 27.4$ \\
\hline F2 & $45.5 \pm 19.5$ & $85.5 \pm 25.0$ & $73.3 \pm 30.1$ & $80.0 \pm 21.9$ & $73.3 \pm 20.8$ & $71.5 \pm 15.4$ \\
\hline F3 & $8.9 \pm 5.1$ & $66.6 \pm 57.7$ & $96.6 \pm 8.2$ & $96.6 \pm 8.2$ & $93.3 \pm 5.8$ & $72.4 \pm 37.7$ \\
\hline F4 & $62.2 \pm 39.7$ & $66.6 \pm 57.7$ & $96.6 \pm 8.2$ & $96.6 \pm 8.2$ & $93.3 \pm 5.8$ & $83.1 \pm 17.2$ \\
\hline F5 & $44.4 \pm 45.9$ & $92.2 \pm 7.7$ & $30 \pm 27.5$ & $80.0 \pm 21.9$ & $26.6 \pm 15.2$ & $54.6 \pm 29.8$ \\
\hline F6 & $77.7 \pm 38.4$ & $100 \pm 0.0$ & $63.3 \pm 8.2$ & $60.0 \pm 30.9$ & $26.6 \pm 15.2$ & $65.5 \pm 26.9$ \\
\hline F7 & $27.7 \pm 5.1$ & $1.1 \pm 1.9$ & $20 \pm 17.8$ & $10 \pm 10.9$ & $3.3 \pm 5.8$ & $12.4 \pm 11.3$ \\
\hline F8 & $56.6 \pm 32.8$ & $80.0 \pm 10.0$ & $53.3 \pm 32.6$ & $26.6 \pm 30.1$ & $26.6 \pm 11.5$ & $48.6 \pm 22.6$ \\
\hline F9 & $30.0 \pm 3.3$ & $66.6 \pm 57.7$ & $43.3 \pm 19.6$ & $56.6 \pm 23.3$ & $3.3 \pm 5.8$ & $40.0 \pm 24.7$ \\
\hline Wild_1 & $15.5 \pm 18.3$ & $60.0 \pm 29.0$ & $63.3 \pm 15.0$ & $66.6 \pm 16.3$ & $46.6 \pm 32.1$ & $50.4 \pm 20.9$ \\
\hline Wild_2 & $74.4 \pm 21.4$ & $98.8 \pm 1.9$ & $86.6 \pm 24.2$ & $73.3 \pm 27.3$ & $66.6 \pm 15.2$ & $79.9 \pm 12.8$ \\
\hline Wild_3 & $88.8 \pm 10.7$ & $33.3 \pm 57.7$ & $86.6 \pm 16.3$ & $86.6 \pm 16.3$ & $76.6 \pm 20.8$ & $74.4 \pm 23.4$ \\
\hline Mean & $47.0 \pm 25.4$ & $70.9 \pm 29.7$ & $67.2 \pm 26.3$ & $68.3 \pm 26.8$ & $50.2 \pm 32.4$ & $60.7 \pm 29.1$ \\
\hline
\end{tabular}

